\title{
射出成形における可塑化過程 の熱エ学的研究
}

\author{
藤井哲・辻俊博* \\ 田中宏史
}

九州大学 生碎科学研究所 ${ }^{\dagger}$

\begin{abstract}
スクリューレスタイプの射出成形機内の可塑化過程が，摩擦発熱を伴う 1 次元溶融润題のモデル

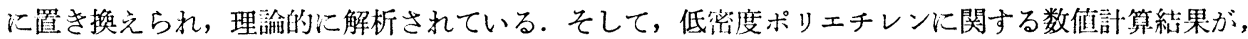
温度分布执よび無次元溶融完了時間と指数則変形ブッンクマン数との関係について示されている. さらに，この関係が实機の実験によって確かめられている。そのほか，実機と物理モデルとの対応 関倸より定義された理諭最大押し出し流量は, 溶融状態子测の指標となるのみならず，機械似設就 に関する諸量に関しても基本望となることが示されている。
\end{abstract}

\section{緒言}

熱可塑性樹脂の成形加工において，身出成形の占める 割合が増加すると共に, 成形サイクルの短縮, 成形精度 の问上などが要求されてきている. 射出成形は周期的サ イクルであり，ポリマー特有の物性の影歓および複雑な 相変化の過程を伴うため, その熱工学的基礎研究が行わ れるようになったのは比較的最近である。しかも，それ はスクリュー射忚成形機に闺するものに限られているよ らである2).

本献では，外解加熱と溶融ポリマーの摩擦発熱の効果 を作用するスクリニーレスタイプの二重円筒構造の射出 成形機を取り上げる。この機械の可望化部では, ポリマー

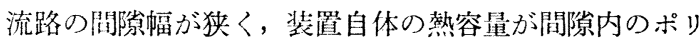
マーの熟容量に比して非常に大きく, かつ高温, 高圧で あるので溶融機棈解明のための冷却可視化実験や固相と 液相の境界括よでこれぞれの相の温度分布・速度分布な ぞの娜定はきわわ困難である，てこで，本報では間隙 内の浴融過程を有限領域の非定常 1 次元相変化モデルに 置さ換え，天れに関寸る解析結果を利用して，実機の特 性の解明を鵤多る。

\section{1. 実際の可塑化過程とモデルとの対応}

本学験に使用した射出成形機の可塑化部を Fig. 1 に 示す。そそれはハウジング (外筒) 拈よび回転棒（通称ス ピンナ）から成り，ハウジングはバンドヒータにより加 熱され，スピンナはトルクモータで回転を与えられる。 ペレット状の国体ポリマーが可塑化胡に供給され，上方 よりスタッファプランジャが下降すると同時にスピンナ が回枟し，溶融ポリマーが押し出される．溶融押し出し ぶ完了するとプランジャは再び元り位罚まで上昇し，停

$+\quad 812$ 福岡甫東区箱崎

* 名古屋工藻大”学 機械工学科
止した状䔶で国体ポリマーが供給され，一つのサイクル が終了する。

Fig. 1 に扝いて，ポリマーが外筒と内简の閪隌を軸方 向へ流動している時の任意の断面 $\mathbf{A}-\mathbf{A}$ に注日する. ペ レットが高王で押し付けられていること, 軸方向への流 動速度が内筒の周速度に比べて非常に小さいこと, 軸方 向の熱伝劓が半径方向のそれに比して無視できるほど小 さいこと，間隙が十分小さいことなどから，断面 $\mathbf{A}-\mathbf{A}$ にあるポリマーと共に軸方向に移動する座標系につい て Fig. 2 に示すモデルを考える.すなわち, それはは ごめに幅 $h$ の一様温度の固体ポリマーを温度 $T_{1 w} お よ$ び $T_{2 w}$ の壁によって加熱すると同時に, 壁 1 を一定速 度 $V$ で動かし, 液相において摩擦発熟させる非定常 1 次元閌題である. もし Fig. 1 のスピンナの下滥位置で 溶融が完了するとすれば，その状態はFig. 2 において， 囷体部分が消隇する時間に対応するわ忛である。

\section{2. 基碤式および積分法による近似解}

Fig. 2 において, 座標 $x$ は䡊動している壁から国定 壁に问かって取る. 温度 $T_{1}, T_{2}, T_{3}$ (初期温度基準の相 対温度), 溶融厚さ $\delta_{1}, \delta_{2}$ は図示したと㧍りである. そ して次の仮定を置く. (1) 温度伝導率 $\kappa_{l}, \kappa_{8}$ (添字 $l, s$

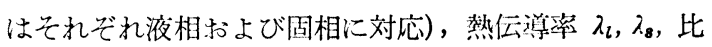
熱 $C_{l}, C_{8}$ および密度 $\rho_{l}=\rho_{8}$ は温度に依存せず, 溶融 温度 $T_{m}$ および溶融の潜熱 $L$ は一定であり, 粘度 $\mu_{l}$ は温度依存性と非ニュートン性をもつものとする，(2) $x$ 方向の速度成分は無視できるほど小さい，乙の場合， 高粘性流体の解の速度分布には非定常項が現れないこと がわかっているので゙), 運動方程式に拉けるその項はは じめから無視することにする.

上㲹の仮定より，基礎式は次のようになる.

$$
\frac{\partial \tau_{i}}{\partial x}=0 \quad(i=1,2)
$$




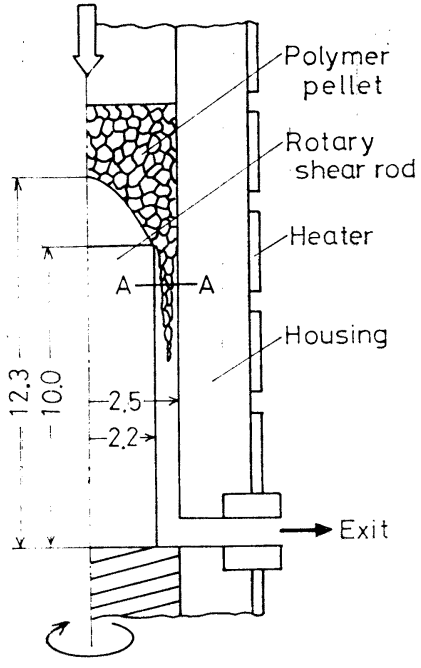

Fig. 1 A sketch of plasticating section

$$
\begin{aligned}
\frac{\partial T_{i}}{\partial t} & =\kappa_{l} \frac{\partial^{2} T_{i}}{\partial x_{2}}+\frac{\tau_{i}}{\rho C_{l}} \frac{\partial v_{i}}{\partial x} & (i=1,2) \\
\frac{\partial T_{3}}{\partial t} & =\kappa_{s} \frac{\partial^{2} T_{3}}{\partial x^{2}} & \\
\tau_{i} & =\left\{\ell_{i}\left(T_{i}\right)\right\}^{1 / n}\left|\frac{\partial v_{i}}{\partial x}\right|^{1 n-1} \frac{\partial v_{i}}{\partial x} & (i=1,2) \\
\mu_{i}\left(T_{i}\right) & =\mu_{m} \exp \left\{\beta\left(T_{i}-T_{m}\right)\right\} & (i=1,2)
\end{aligned}
$$

ここに テ

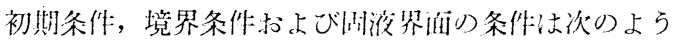
になる。

$$
\begin{aligned}
& \begin{array}{llll}
t=0 & \text { ¿゙, } & T_{3}=0, \quad \delta_{1}=\delta_{2}=0
\end{array} \\
& x=0 \quad \text { で, } \quad T_{1}=T_{1 W^{-}}, \quad v_{1}=V \\
& x=\delta_{1} \text { で, } T_{1}=T_{3}=T_{m} \text {, } \\
& -\lambda_{l} \frac{\partial T_{1}}{\partial x}+\lambda_{8} \frac{\partial T_{3}}{\partial x}=\rho L \frac{d \hat{o}_{1}}{d t} \\
& x=\delta_{1} \quad \text { および } x=h-\delta_{2} \text { で, } \\
& \tau_{1}=\tau_{2}, \quad v_{1}=v_{2} \\
& x=h-\delta_{2} \quad \text { で, } \quad T_{2}=T_{3}=T_{m} \\
& -\lambda_{l} \frac{\partial T_{2}}{\partial x}+\lambda_{8} \frac{\partial T_{3}}{\partial x}=-\rho L \frac{d \hat{\delta}_{2}}{d t} \\
& x=h \text { で, } \quad T_{2}=T_{2 w}, \quad v_{2}=0
\end{aligned}
$$

方和式总解く汇際して，まず次の無次元数学酱入する.

$$
S=\kappa_{l} t / h^{2}
$$

$$
x_{1}=\frac{x}{h}, \quad x_{2}=1-\frac{x}{h}, \quad \Delta_{1}=\frac{\delta_{1}}{h}, \quad \Delta_{2}=\frac{\delta_{2}}{h}
$$

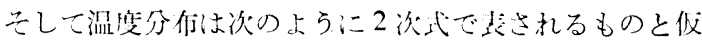
定する、液相で法，

$$
\frac{T_{i}-T_{m}}{T_{2 w}-T_{m}}=a_{i}\left(1-\frac{x_{i}}{\Delta_{i}}\right)\left(\frac{b_{i}}{a_{i}}-\frac{x_{i}}{\Delta_{i}}\right) \quad(i=1,2)
$$

ここで $a_{i}$ は未定で， $b_{i}$ は筧界条件 Eqs. (7)，(15)上り，

$$
b_{1}=\frac{T_{1 w}-T_{m}}{T_{2 w}-T_{m}}=R_{T}, \quad b_{2}=1
$$

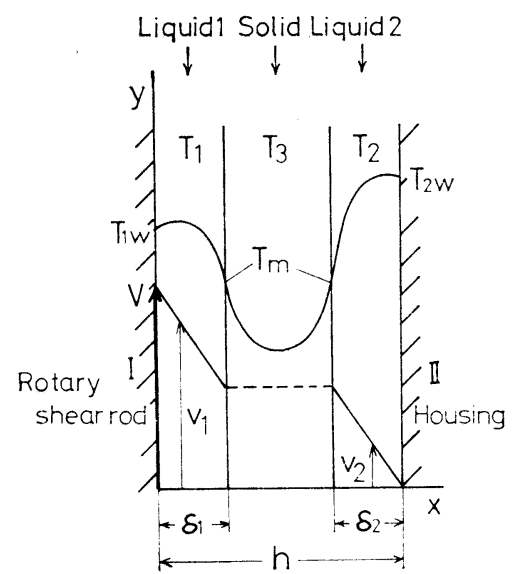

Fig. 2 Physical model and coordinates

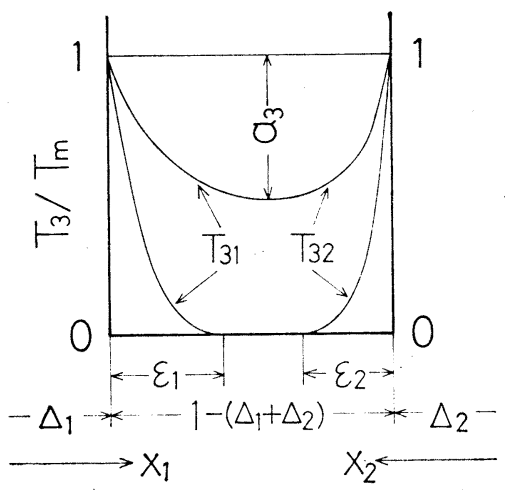

Fig. 3 Thermal boundary layer in solid phase

|间相では，Fig. 3 に示すような温度境界層を考えると， $\Delta_{i} \leqq x_{i} \leqq \Delta_{i}+\varepsilon_{i}$ で,

$$
\frac{T_{3 i}}{T_{m}}=a_{3}\left(1-\frac{x_{i}-\Delta_{i}}{\varepsilon_{i}}\right)^{2}+\left(1-a_{3}\right) \quad(i=1,2)
$$

煳相内の二つの温度境界層が接する时阔 $S_{0}$ までは， $x_{i}=$ $\Delta_{i}+s_{i}$ で $T_{3 i}=0$ であるから $a_{3}=1$ となるが，てれ以 後すなわち，

$$
\varepsilon_{1}+\varepsilon_{2}=1-\left(\Delta_{1}+\Delta_{2}\right)
$$

と交るところでは， $a_{3}$ は Fig. 3 に示す䟲さに対応する. 次に無次元温度分布の液相の領域拈上び固相の温度境 界㦄内全体にわたる積分をそれぞれ次式で定義する。

$$
\begin{aligned}
\theta_{i} & =\int_{0}^{\lrcorner_{i}} \frac{T_{i}-T_{m}}{T_{2 w}-T_{m}} d x_{i} \quad(i=1,2) \\
\theta_{3 i} & =\int_{0}^{\lrcorner_{i}+s_{i}} \frac{T_{3 i}}{T_{m}} d x_{i} \quad(i=1,2)
\end{aligned}
$$

$\theta_{i}$ および $\theta_{3 i}$ が確定すれば，上記の未定数 $a_{i}, a_{3}$ 法 Eqs. (19), (21) 上り，次のようになる.

$$
a_{i}=\frac{3 b_{i} \Delta_{i}-6 \theta_{i}}{\Delta_{i}}
$$

$$
a_{3}=1 \quad\left(0<S \leqq S_{0}\right), \quad \frac{3}{2}\left\{1-\frac{\theta_{31}+\theta_{32}}{1-\left(\Delta_{1}+\Delta_{2}\right)}\right\}
$$




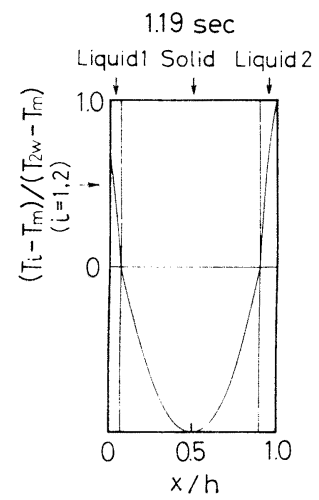

$3.20 \mathrm{sec} \quad 11.25 \mathrm{sec}$
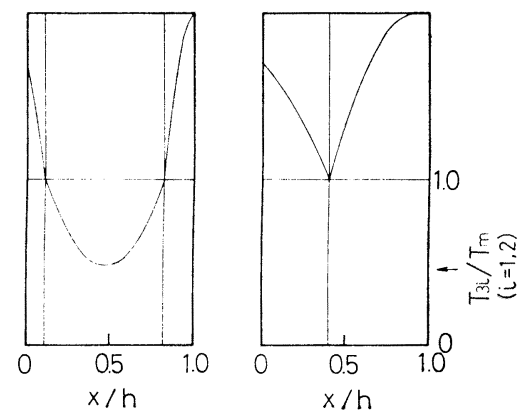

Fig. 4 An example of temperature distribution calculated for lowdensity polyethylene

液相の速度分布は, Eqs. (1)，(4)，(5) を $x_{i}$ に関して 積分し，境界条件 Eqs. (8)，(16) および界面条件 Eqs. (11)，(12）を用いれば，次のようになる.

$$
\left.\begin{array}{rl}
\frac{v_{1}}{V} & =1-\int_{0}^{x_{1}} \frac{d x_{1}}{\eta_{1}} /\left(\int_{0}^{\Delta_{1}} \frac{d x_{1}}{\eta_{1}}+\int_{0}^{\iota_{2}} \frac{d x_{2}}{\eta_{2}}\right) \\
\frac{v_{2}}{V} & =\int_{0}^{x_{2}} \frac{d x_{2}}{\eta_{2}} /\left(\int_{0}^{\Delta_{1}} \frac{d x_{1}}{\eta_{1}}+\int_{0}^{\Delta_{2}} \frac{d x_{2}}{\eta_{2}}\right)
\end{array}\right\}
$$

液相の熱エネルギーに関する Eq. (2) を $x_{i}$ に関して 0 から $\Delta_{i}$ まで積分し，界面条件 Eqs. (9), (13) および Eqs. (19), (23), (25), (27) を用いれば次式が得られる.

$$
\frac{d \theta_{i}}{d S}=\frac{6 b_{i} \Delta_{i}-12 \theta_{i}}{\Delta_{i}^{2}}+B r^{*} \varphi_{i} \quad(i=1,2)
$$

ここに,

$$
\begin{aligned}
B r^{*} & =\frac{V h}{\lambda_{l}\left(T_{2 w}-T_{m}\right)}\left(\frac{V \mu_{m}}{h}\right)^{1 / n} \\
\varphi_{i} & =\int_{0}^{\Delta_{i}} \frac{d x_{i}}{\eta_{i}} /\left(\int_{0}^{\Delta_{1}} \frac{d x_{1}}{\eta_{1}}+\int_{0}^{\Delta_{2}} \frac{d x_{2}}{\eta_{2}}\right)^{(n+1) / n}
\end{aligned}
$$

固相の熱伝導に関する Eq. (3) を $x_{i}$ に関して $\Delta_{i}$ か ら $A_{i}+\varepsilon_{i}$ まで積分し, さらに Eqs. (21), (22), (24), (26) を用いれば，

$$
\begin{aligned}
& \frac{d \theta_{3 i}}{d S}= \frac{6 R_{\kappa} r^{2}}{\theta_{3 i}}-3 r \frac{d \Delta_{i}}{d S} \\
& r+(1-3 r)\left\{\frac{3 R_{\kappa}}{\theta_{3 j}}-\frac{\theta_{3 i}}{r\left(\theta_{31}+\theta_{32}\right)} \frac{d\left(\Delta_{1}+\Delta_{2}\right)}{d S}\right\} \\
&(i, j=1,2, \quad i \neq j)
\end{aligned}
$$

$こ こ に$

$$
r=\frac{1}{3}\left(0<S \leqq S_{0}\right), \quad \frac{\theta_{k 1}-\theta_{32}}{1-\left(\Delta_{1}+\Delta_{2}\right)}\left(S_{0}<S\right)
$$

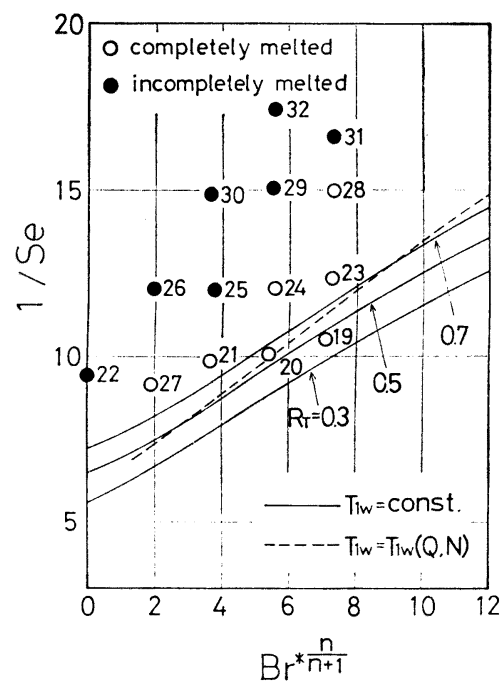

(a) $T_{2 w}=180^{\circ} \mathrm{C}, T_{0}=20^{\circ} \mathrm{C}$

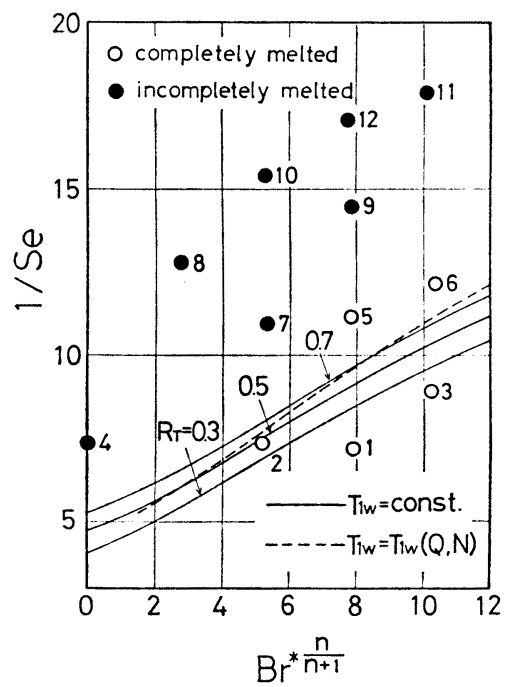

(b) $T_{2 w}=220^{\circ} \mathrm{C}, T_{0}=18^{\circ} \mathrm{C}$

Fig. $51 / S_{e}$ and $\mathrm{Br}^{*}$ are dimensionless numbers proportional to extrude rate and rotational frequency, respectively. Polts about distinction between complete and incomplete melting at the exit of plasticating section, and theoretically predicted lines on which the melting may be just completed.

固液界面の条件 Eqs. (10), (14) 飞 Eqs. (19), (20)を 代入すると次式が得られる.

$$
\begin{aligned}
& R_{h} \frac{d \Delta_{i}}{d S}=\frac{6 \theta_{i}-2 b_{i} \Delta_{i}}{\Delta_{i}{ }^{2}}-\frac{3 R_{q}(1-r) r}{\theta_{3 i}} \quad(i=1,2) \\
& \text { ここに, } \\
& R_{h}=\frac{L}{C_{l}\left(T_{2 w}-T_{m}\right)}, \\
& R_{q}=\frac{\lambda_{s} T_{m}}{\lambda_{l}\left(T_{2 w}-T_{m}\right)}
\end{aligned}
$$

初期条件は， 


$$
S=0 \text { で, } \quad \Delta_{i}=\theta_{i}=\theta_{3 i}=0 \quad(i=1,2)
$$

かくて，温度分布を求めるためには， $\theta_{i}, \theta_{3 i}, \Delta_{i}(i=1,2)$ 汇関与る連立 1 階常微分方程式 Eqs. (29), (32), (35) を 初期条件 Eq. (38) のもとで解けばよいことになる.

なお，固相内で両側から発達してきた温度境界層が接 おる時間は Eq. (26) で $a_{3}=1$ となる条件，すなわち

$$
\frac{\theta_{31}+\theta_{31}}{1-\left(\Delta_{1}+\Delta_{2}\right)}=\frac{1}{3}
$$

で与えられる。

Eqs. (29), (32), (35) を数值的に解く場合に, Eq. (38) り初期条件のままでは計算を進めることができないの で，次のよらにする．まず最初の時問きざみ $\Delta S$ に㧊い て， $\varphi_{i}=\Phi_{i} / \Delta_{i}\left(\Phi_{i}=\right.$ 一定拈よび $\left.r=1 / 3\right)$ と扣き, 解析的 : $\Delta_{i}, \theta_{i}$ を求める. 次にこの $\Delta_{i}, \theta_{i}$ を用いて $\varphi$ を Eq. (31) より計算し，はじめに仮定した $\Phi_{i}$ を繰り返し修正 する (Eq. (31) の計算にはシンプソン $1 / 3$ 則を用いた). 㐨り返し計算の前後で $\Delta_{i}, \theta_{i}$ などの差がすべて $10^{-5}$ 以 下になった場合に，それをルンゲ・クッタ・ジル法によ る数优程分の出発檤とした. 出発値を与える最初の時間 $J S$ は以後の数倬䖽分を進行させて求まる溶融完了時間 $S_{e}$ が 10-4 以下で変動しない程度に小さくとった. 実際 には $\Delta S<10^{-3} \cdot S_{e}$ 程度で十分である. $S=S_{0}$ にお外る条 件 Eq. (39) は $10^{-5}$ 以下の精度で満足するようにした. また浚䗝完了時間に近づくと数値計算が困難になるの で, $r$ の估が $10^{-5}$ 以下の精度で 1 に近つけげ, 固相内 の温度は一様に溶融温度 $T_{m}$ になった $\left(a_{3}=0\right)$ ものと 考え, 以後は $r=1$ として Eqs. (29), (35) を連立させ て計算を進めた。なお，粘度が温度に依存しないニュー トン流体の場合には Eqs. (25), (32), (35) に解析解があ る. その場合に数倏解と解析解は $10^{-4}$ 以下の精度で一 致した ${ }^{3)}$.

物性任については, 実験に朋いた武料ポリエチレンに 刘応する次の値を採用した ${ }^{1)}$.

$$
\begin{aligned}
& \rho=0.8375 \mathrm{~g} / \mathrm{cm}^{3}, \quad C_{l}=0.62 \mathrm{cal} / \mathrm{g} \cdot{ }^{\circ} \mathrm{C}, \\
& C_{\mathrm{s}}=0.55 \mathrm{cal} / \mathrm{g} \cdot{ }^{\circ} \mathrm{C}, \quad \lambda_{l}=4.34 \times 10^{-4} \mathrm{cal} / \mathrm{cm} \cdot \mathrm{sec} \cdot{ }^{\circ} \mathrm{C}, \\
& \lambda_{s}=8.27 \times 10^{-4} \mathrm{cal} / \mathrm{cm} \cdot \mathrm{sec} \cdot{ }^{\circ} \mathrm{C}, \\
& \kappa_{l}=8.36 \times 10^{-4} \mathrm{~cm}^{2} / \mathrm{sec}, \\
& \kappa_{s}=17.95 \times 10^{-4} \mathrm{~cm}^{2} / \mathrm{sec}, \quad T_{m}=111^{\circ} \mathrm{C}, \\
& L=31 \mathrm{cal} / \mathrm{g}, \quad \mu_{m}=2.976 \times 10^{13} \mathrm{sec}\left(\mathrm{g} / \mathrm{cm} \cdot \mathrm{sec}^{2}\right)^{n}, \\
& \hat{\beta}=-2.31 \times 10^{-2} 1 /{ }^{\circ} \mathrm{C}, \quad n=2.496
\end{aligned}
$$

Fig. 4 は温度分布の一例を示したものである. Figs. 5(a), (b) の実線は，それぞれ $T_{0}=20^{\circ} \mathrm{C}, T_{2 w}=180^{\circ} \mathrm{C}$ お 々び $T_{0}=18^{\circ} \mathrm{C}, T_{2 w}=220^{\circ} \mathrm{C}$ の場合における, パラメー 夕 $R_{T}=0.3,0.5,0.7$ の場合の数值解を無次元溶融完了 時阔 $S_{e}$ と指数則変形ブリンクマン数 $B r^{* h /(n+1)}$ との関 係で示したものである. 壁の速度 $V$ の增加と共に $1 / S_{e}$

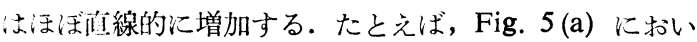

て, $h=0.3 \mathrm{~cm}, V=50 \mathrm{~cm} / \mathrm{sec}$ で $B r^{* n /(n+1)} \fallingdotseq 10$ とな り, 外部加熱のみで溶融する場合 $\left(B r^{* n /(n+1)}=0\right)$ と比 べ溶融完了時間が約 $1 / 2$ になることがわかる.

\section{3. 実験結果および考察}

本実験では次の諸量を測定した。（1）1サイクルの押 し出し量 $m$ 一一押し出し後重量測定. (2) ハウジング温 度 $T_{2 w}$, スピンナ温度 $T_{1 w}$ 扎よびポリマー温度 $T_{P}$ それぞれ軸方向に 4,6 抢よび 3 個のシース熱電対を取 り付けた. いずれも若干時間的変動があるが， $T_{2 w}$ はほ ぼ一様になるように制御され， $T_{1 w}$ は押し出し方向に温 度が高くなる. (3) ポリマー圧力 $P$ 一一軸方向に 3 個所, 出口付近に 1 個所の測定孔を取り付けた. (4) スピンナ 回転数 $N$, プランジャ下降速度, スピンナトルク $T_{o r}$ お よびスタッファ压力 $P_{s t}$. 以上 $(2) \sim(4)$ の值は電磁才 シログラフとデータ集録器に記録した. (5) 押し出し時 間 $t_{e x}$ —トルクとスタッファ圧力のオシログラムより 求めた.

試料には低密度ポリエチレン(UBE·J-519) を用いた. 実験条件としては, $T_{2 w}=180^{\circ} \mathrm{C}$ および $22^{\circ} \mathrm{C}, N=0 \sim$ $240 \mathrm{rpm}$, 押し出し時間 $t_{e x}=15 \sim 45 \mathrm{sec}$ を選んだ. 1 サイ クルで供給されるポリマーの約 $1 / 2$ がそのサイクルで押 し出されるようにして, 約 10 サイクル後よりすべての 测定量について定常サイクルが得られる(測定装置およ びデータの詳細は文献 (3)).

ポリマーはほぼ一定速度 $U$ で押し出されるので押し 出し流量 $Q$ は次式で与兄られる.

$$
Q=m / \rho \cdot t_{e x}
$$

特に, スピンナ有効長さ $l(=10 \mathrm{~cm})$ で溶融が完了する時 開 $t_{e}(=l / U)$ に対する押し出し流量 $Q_{\max }\left(Q<Q_{\max }\right.$ の場 合には途中で溶融が完了する）は次式で与えられる.

$$
Q_{\max }=\pi\left(R_{1}+R_{2}\right) h \cdot l / t_{e}
$$

ここに, $R_{1}$ はスピンナ外半径, $R_{2}$ は八ウジング内半径, $h$ は間隙幅 $\left(=R_{2}-R_{1}\right)$.

$t_{e} を$ Eq. (17) で無次元化したものが Fig. 2 のモデ ルについての理論解析から求をる溶融完了時間 $S_{e}$ に等 しいと考えれば，Eq. (14) は次のようになる.

$$
\frac{1}{S_{e}}=\frac{Q_{\max } \cdot h}{\pi\left(R_{1}+R_{2}\right) l \cdot \kappa_{l}}
$$

Eq. (42) で定義される $Q_{\max }$ を理論最大押し出し流量 ということにする. また，モデルの $V$ はスピンナの周 速度に対応寸るので, $N=60 V / 2 \pi R_{1}$ の関係がある. し たがって，Eq. (30) より次式が導かれる.

$$
B r^{* n /(n+1)}=\left\{\frac{h}{\lambda_{l}\left(T_{2 w}-T_{m}\right)}\left(\frac{\mu_{m}}{h}\right)^{1 / n}\right\}^{n /(n+1)} \frac{2 \pi R_{1} N}{60}
$$

設定されたハウジング温度，スピンナ回転数に対して 

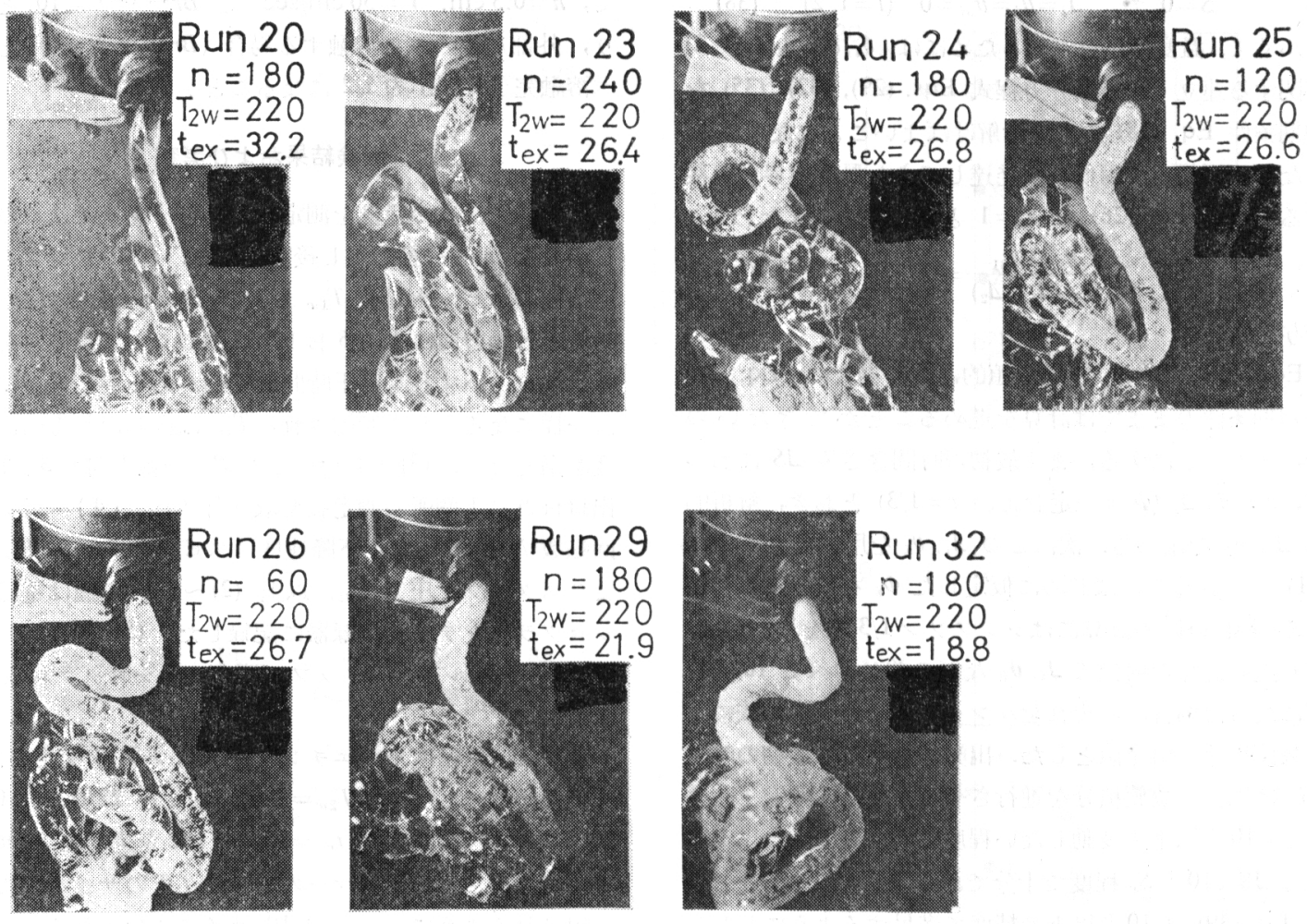

Fig. 6 Comparison of the feature of polymer melt at the exit

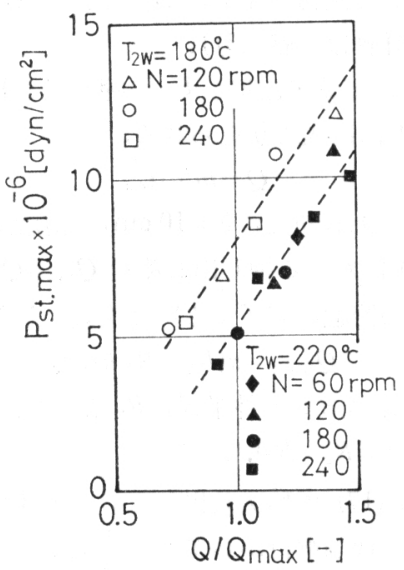

回転数を增加させた場合, Run 20,24, 29, 32 は回転数 一定で押し出し流量を増加させた場合に対応する。完全 溶融か不完全溶融かを厳密に判定することは困難である が，回転数が增加すれば，溶融状沉は良好になり，ほぼ 透明なポリマーが押し出され，また押し出し流量が増加 すれば，未浴融部が增加して不透明になる。

Figs. 5(a)，(b)にプロットした○印は完全溶融状態， -印法不完全溶融状態と又なされるものであって（横の 数字は Run No.), 縦軸の $1 / S_{e}$ の值は Eq. (42) 飞打 汀る $Q_{\max }$ の值に实際の流量を代入して算出したもので ある。

実験において，ハウジング温度 $T_{2 w}$ は適当に設定さ れるが，スピンナ温度の平均值 $T_{1 w}$ は $Q, N$ 预よび $T_{2 w}$ の関数となる. 本実験では, 次式で表される関係

$$
T_{1 w}=-2.34 Q+0.135 N+\text { const. }\left(T_{2 w}\right)
$$

が得られたのでこれを用いて計算された理論最大流量 に関する曲線が Figs. 5(a), (b) そ示可鎖線である.さら に厳密にはスピンナ温度は軸方向にも変化しているので あるが，とれを考虑した理論計算は平均值を用いたるの と溶融時間について，1\%以下の精度で一致する ${ }^{3)}$.

Figs. 5(a),(b)のプロットより推定される完全溶融と不 完全溶融との境界は理論的予測線の傾向とほぼ一致し, しかも $1 / S_{e}$ の理論的予測値は完全溶融を十分に保証す る側にわずかに低くなっているとみなしてょい。 
Fig. 7 に押し屾し終了直前に現れるスタッファ最高压 力 $P_{8 t \max }$ と $Q / Q_{\max }$ との関係を示す. $Q / Q_{\max } \leqq 1$ は 完全溶融押し出し，Q/Q $Q_{\max }>1$ は不完全溶融押し出し に対応している. $P_{8 t \max }$ は, 回転数 $N$ に無関係に, ほぼ $Q / Q_{\text {max }}$ に対して西線的に増加する.ただしハウ ジング温度が高い場合には, 溶融ポリマーの粘度低下に より $P_{8 t \max }$ は少し下る. 同㥞の倾向はやはり押し山し 終了直前に現れるトルクの最高值 $T_{\text {or } \max }$ と $Q / Q_{\mathrm{nnx}}$ との関係にもある3).

以上に示した占らに，Eq. (42) で定義された理渝最大 押し出し流星は, 溶融状態の予测のみならず，スタッフ ア最高王抽トルクの最高佔など機械的設尌に必装なデ

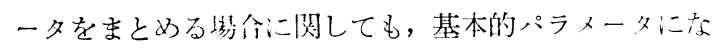
っているのである.

\section{結 言}

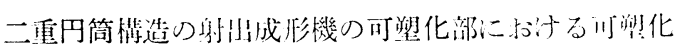
過程を, 有限厚さの板の非定常溶融過程にモデル化し， それに関する方程式の积分法による解を示した。 元して 溶融ポリマーの摩擦発熱の効果により溶融完了版間をか なり短縮できることを無次元溶融洔間 $S_{e}$ と指数剘劣形 ブリンクーン数 $B r^{* n /(n+1)}$ との関係で示した.

モデルに関する解から得られる溶融完了時間をボリマ 一がハウジングとスピンナの閶隚を通過する時阔と結び つけることによって, 理淪最大押し出し流量の舤次元数 とスピンナ回転数の無次元数との凰係がモデルの解 $1 / S_{e}$ 対 $B r^{* n /(n+1)}$ の関係に対応するものであることを示し， それは寒機にお壮る完全溶融条件をかなり正碓に了渭す るものであることを实证した。

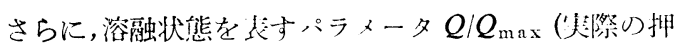
乙出し流星と理渝最大押し出し流早との比）は大タッフ

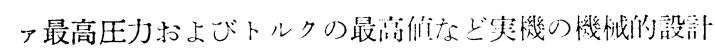
に関する諸星について基本涽となることを示した。

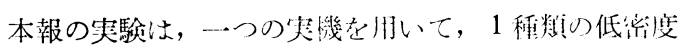
ポリエチレンについて行ったものであるが，解析方法沈 同形式の可塑化装温には一般的に適用できる.さらにて れは類似の可塑化過䅙に阅する解析にも有效であるう。

[謝辞]本诟究は宇部興座(株) ・宇部鉄工所心访 力と援助によっこはじめられたものである. 藤野清・ 所長はじめ担当の方々に深謝する.さらに装置の改良む よで実験に際して, 本研究室の泉正道技官の協力を得た. また当時学生の鶴岡一広, 柴田宗広, 小山繁の諸石が 卒業研究として参加した。

\section{Nomenclature}

$B \quad=$ constant defined by Eq. (28)

$B r^{*}=$ Brinkman number for power law fluid defined by Eq. (30)

$[-]$

$=$ specific heat

$\left[\mathrm{cal} / \mathrm{g} \cdot{ }^{\circ} \mathrm{C}\right]$

$=R_{1}-R_{2}$

[cm]

$L=$ latent heat of fusion $\quad[\mathrm{cal} / \mathrm{g}]$

$l=$ effective length of rotary shear rod [cm]

$m=$ mass of polymer extruded per cycle

$N=$ rotational frequency of rotary shear rod

[g]

$n \quad=$ index for power law fluid

[rpm]

$[-]$

$P \quad=$ polymer pressure $\quad\left[\mathrm{dyn} / \mathrm{cm}^{2}\right]$

$P_{s t}=$ pressure in stuffer chamber $\quad\left[\mathrm{dyn} / \mathrm{cm}^{2}\right]$

$Q \quad=$ extrude rate $\quad\left[\mathrm{cm}^{3} / \mathrm{sec}\right]$

$Q_{\max }=$ theoretical maximum extrude rate

$R_{1}=$ outer radius of rotary shear $\operatorname{rod} \quad[\mathrm{cm}]$

$\begin{array}{ll}R_{2} & =\text { inner radius of housing [cm] }\end{array}$

$R_{h} \quad=$ ratio of latent heat to sensible heat defined by Eq. (36)

$R_{q}=$ conduction heat ratio defined by Eq. (37)

$R_{T} \quad=$ wall temperature ratio defined by Eq. (20)

$R_{\boldsymbol{\kappa}}=$ thermal diffusivity ratio defined by

$r \quad \begin{aligned} \text { Eq. (33) } \\ r \quad \text { function }\end{aligned}$

$r \quad=$ function defined by Eq. (34)

$[-]$

$S=$ dimensionless time

$S_{e}=$ dimensionless time for

complete melting [-]

$T_{m}=$ melting temperature, constant [ C]

$T_{o}=$ initial temperature of polymer pellets $\left[{ }^{\circ} \mathrm{C}\right]$

$T_{p}=$ polymer temperature

$\left[{ }^{\circ} \mathrm{C}\right]$

$T_{1}, T_{2}=$ liquid temperature as shown in Fig. 2

[C]

$T_{3}=$ solid temperature as shown in Fig. $2[\mathrm{C}]$

$T_{1 w}=$ temperature at wall in contact with liquid phase 1 as shown in Fig. 2 and temperature of rotary shear rod

$T_{2 w}=$ temperature at wall in contact with liquid phase 2 as shown in Fig. 2 and temperature of housing

[C]

$T_{\text {or }}=$ torque

[dyn $\cdot \mathrm{cm}$ ]

$t=$ time

$r_{e}=$ time for complete melting

[sec]

$t_{e x}=$ time for extruding period

[sec]

$U=$ mean velocity of polymer in axial direction

[sec]

V

$=$ velocity of wall in contact with liquid

phase 1 as shown in Fig. $2 \quad[\mathrm{~cm} / \mathrm{sec}]$

$[\mathrm{cm} / \mathrm{sec}]$

$v \quad=$ liquid velocity as shown in Fig. $2[\mathrm{~cm} / \mathrm{sec}]$

$x, y=$ coordinates as shown in Fig. $2 \quad[\mathrm{~cm}]$

$\beta \quad=$ constant defined by Eq. (5) $\quad[1 / \mathrm{C}]$

$\Delta \quad=$ dimensionless melt thickness defined by Eq. (19)

$[-]$

$\delta \quad=$ melt thickness as shown in Fig. $2 \quad[\mathrm{~cm}]$

$\varepsilon \quad=$ dimensionless thermal boundary layer thickness in solid phase as shown in Fig. 3 
$\eta \quad=$ dimensionless viscosity defined by Eq. (28)

$\theta=$ dimensionless temperature defined by Eqs. (23), (24)

$\kappa=$ thermal diffusivity

$\lambda=$ thermal conductivity

$\mu \quad=$ viscosity

$\mu_{m} \quad=$ constant defined in Eq. (5)

$\rho \quad=$ density

$\tau \quad=$ shear stress

$\varphi \quad=$ function defined by Eq. (31)

$\langle$ Subscripts〉

$1=$ liquid phase 1

$2=$ liquid phase 2
$3,31,32=$ solid phase

$l=$ polymer melt

$s \quad=$ polymer pellet and/or solid

$\langle$ Superscript $\rangle$

- $\quad=$ values average over time and/or measuring location

$\left[\mathrm{cal} / \mathrm{cm} \cdot \mathrm{sec} \cdot{ }^{\circ} \mathrm{C}\right.$ ]

$[\mathrm{g} / \mathrm{cm} \cdot \mathrm{sec}]$

$\left[\mathrm{sec}\left(\mathrm{g} / \mathrm{cm} \cdot \sec ^{2}\right)^{n}\right]$

$\left[\mathrm{g} / \mathrm{cm}^{3}\right]$

$\left[\mathrm{g} / \mathrm{cm} \cdot \mathrm{sec}^{2}\right]$

$[-]$

\section{Literature cited}

1) Donovan, R. C.: Polym. Eng. Sci., 11, 361 (1971)

2) Lipshitz, S. D., R. Lavic and Z. Tadmer: ibid., 14, 553 (1974)

3) to be published in The Reports of Research Institute of Industrial Science, Kyushu University

(1978 年 5 月 29 日受理; 第 12 回日本伝熱シンポジウム（福闭， 1975 年 5 月) にて発表)

\title{
Plasticating Process in an Injection Molding Machine
}

\author{
Tetsu Fujii, Toshihiro Tsuji* and Hiroshi Tanaka
}

Research Inst. of Industrial Science, Kyusu Univ., Fukuoka 812

A theoretical analysis is presented of a heat conduction problem in which a solid plate is melted by both external heating and frictional heat in the polymer melt, which is a physical model substituted for the plasticating process of solid polymer in a screwless injection molding machine.

A few examples of numerical results for low-density polyethylene are shown concerning the temperature distributions within the melted and solid polymer and about the relationship between dimensionless complete melting time and modified power-law Brinkman number. The latter is confirmed by observation of molten features of polymer extruded under various machine variables. Furthermore, it is shown that such data as the maximum value of pressure in stuffer chamber are also correlated by a theoretical maximum extrusion rate, which is defined by the correspondence between the real machine and the physical model for complete melting.

* Nagoya Inst. of Tech. 